\title{
Immediate recall of nominalizations and adjectivalizations
}

\section{JANICE BRIEM ${ }^{1}$ AND KATE LOEWENTHAL? DEPARTMENT OF PSYCHOLOGY, UNIVERSITY COLLEGE OF NORTH WALES, Bangor, Wales}

Immediate recall of lists of 3-syllable nouns and adjectives is as good as that reported for monosyllabic words. Lists of nominalizations and adjectivalizations of comparable frequency of occurrence to the nouns and adjectives are, by comparison, poorly retained. It is suggested that nominalizations and adjectivalizations behave as two-chunk items when they are stored in immediate memory.

A recent study by Savin \& Perchonok (1965) indicates that the space occupied in STM by simple sentences can be predicted better from the number of grammatical transformations the sentences contain (Chomsky, 1957) than from sentence length. The present small-scale experiment is an analogous one; we were interested in discovering whether "transformed words"-nominalizations and adjectivalizations-occupy more space in STM than "basic" nouns and adjectives, where the factors of length and frequency of occurrence are held constant.

Nominalizations and adjectivalizations each consist of two morphemes- we, therefore, also examined the immediate recall of two other kinds of two-morpheme items: (a) grammatical adjective-noun combinations, and (b) ungrammatical nounadjective sequences, and anomalous adjective-noun combinations.

Subjects. The Ss were 12 undergraduate students from the University College of North Wales, Bangor. There were 10 women and two men.

Materials. There were six lists, each of 10 3-syllable items. The frequencies of words in lists BN, BA, N, and A were all between one and 10 times per million in the Thorndike-Lorge (1944) count.

BN (Basic nouns): rectangle, chivalry, blasphemy, migration, dimension, parasite, equity, dialect, diplomat, cannibal.

BA (Basic adjectives): affable, facetious, masculine, impartial, despondent, affected, plausible, trivial, aggressive, eccentric.

N (Nominalizations): alertness, abstraction, gallantry, rarity, heaviness, greediness, haughtiness, lawlessness, fickleness, kindliness.

A (Adjectivalizations): bacterial (this 4-syllable word was included by accident), capricious, climatic, bountiful, malicious, hazardous, cavernous, fallacious, deceitful, leisurely.

G (Grammatical phrases): happy boy, many times, common man, naughty girl, coffee break, funny man, sunny day, good morning, duffle coat, broom handle. This list was compiled from the responses of five people asked to give the first two adjective-noun combinations which occurred to them; this procedure was perhaps unfortunate in that some of the items so obtained might be considered almost as single morphemes - notably "good morning."

U (Ungrammatical and anomalous sequences): hat happy, tongue able, road loose, grip heavy, loft sloppy, plush chimney, snow magic, high powder, trite monkey, basin slow. This list was constructed by randomly collocating nouns and adjectives.
Procedure. The Ss were tested individually, and each $\mathrm{S}$ was tested on all six lists. A predecessor-balanced Latin Square design was used to determine order of presentation of the lists. Each list was read at the rate of one item per sec, and was followed by immediate spoken recall, with correct responses being recorded by $\mathrm{E}$. A 2-min rest period was given after every two lists.

Results. The mean numbers of items correctly recalled from each list were BN: $5.4, \mathrm{BA}: 5.7, \mathrm{~N}: 3.9, \mathrm{~A}: 3.8, \mathrm{G}: 6.0, \mathrm{U}: 3.0$. Interlist variance was significantly great $(F=16.2, \mathrm{df}=5 / 50 \mathrm{p}<$ $.001)$, and so was intersubject variance $(F=7.26, \mathrm{df}=11 / 50 \mathrm{p}<$ $.001)$.

Related $t$ tests showed that lists $B N, B A$, and $G$ did not differ significantly from each other, but that each did differ significantly from each of $N, A$, and $U$. Lists $N, A$, and $U$ did not differ significantly from each other.

Discussion. The material learned in this experiment clearly divides itself into two groups. One group consists of basic nouns and adjectives, and grammatical noun-adjective phrases, where $5.4-6.0$ items can be recalled; this is very close to the usual immediate memory span for monosyllabic English words-Miller's (1956) "magical number seven, plus or minus two." We therefore conclude that the trisyllablic nouns and adjectives, and the common noun-adjective phrases, are functioning as single-chunk items.

The other group of material consists of nominalizations and adjectivalizations ( 3.9 and 3.8 items recalled, respectively), and the set of ungrammatical and anomalous phrases (only 3.0 items recalled). Nominalizations and adjectivalizations are retained almost as poorly as the two-chunk items which the ungrammatical and anomalous phrases clearly are.

There is a further factor leading to difficulty in recalling nominalizations and adjectivalizations. (We are grateful to Alex MacRae for this suggestion.) Several nominalizations have the same suffix (-ness), and so do several adjectivalizations (-ous). This might have led to increased confusibility; however, this possibility does not seem to disqualify the main conclusion that nominalizations and adjectivalizations are acting as two-chunk items.

The main conclusions are then, first, that single words need not always act as single "chunks" in STM. Nominalizations and adjectivalizations seem to be stored as two chunks-a stem and a transforming suffix. Secondly, easilyelicited, two-word phrases appear to act as single-chunk items.

\section{REFERENCES}

CHOMSKY, N. Syntactic structures. The Hague: Mouton, 1957.

MILLER, G. A. The magical number seven, plus or minus two: some limits on our capacity for processing information. Psychol Rev., 1956, 63, $81-97$.

SAVIN, H. B., \& PERCHONOK, E. Grammatical Structure and the Immediate Recall of English Sentences. J. verbal Learn. verbal Behav., $1965,4,348-353$.

THORNDIKE, E. I. \& LORGE, I. The teacher's book of 30,000 words. New York: Columbia University, 1944.

NOTES

1. The experiment was executed by the first author in partial requirement for the B. A. degree in the University of Wales.

2. The second author wishes to acknowledge the financial support of the Medical Research Council. 